\title{
HIDĀYAHAS A SOCIAL REALITY The Dynamics of Religiosity Among Muslim Professionals in Surabaya
}

\author{
Rr. Suhartini | UIN Sunan Ampel Surabaya - Indonesia \\ suhartini.rofiq@gmail.com
}

\begin{abstract}
This paper examines the perceptions and experiences of Muslim professionals in Surabaya regarding bidayah (guidance). The descriptive-qualitative method with a phenomenological approach is used to describe the experiences of Muslim professionals concerning the social reality of hidayah in their life. The findings of this paper suggest that the innate "bidayah of religion (bidayat al-din)" from childhood develops in collaboration with the "bidayah of intellect (bidayat al- aqh)" dynamically. In this case, the findings further maintain, the interaction of "religious hidayab" and "aql is affected by the presence of preachers who have various religious educational backgrounds and the availability of religious contents developed through communication and information technology. Thus, the concept of hidayah is an open sphere that is continuously discussed by Muslim professionals in order for them to be trustworthy, honest, and responsible persons. Above all, the paper finds that the guidance of religion and the admonition of reason are intertwined in determining the social actions of Muslim professionals in their life.
\end{abstract}

Keywords: Dinamics of religiosity, Muslim professionals, bidāyah, social reality

\section{Introduction}

Religion is a human, historical, social, and cultural phenomenon. Therefore, it is reasonable that religious ideas, practices, and social expressions are in constant change. In this sense, religious dynamics are a product of individual performance and group processes that can be shaped by new agents and new events. Changes can also be analyzed as a sequence of changes in time. 
Generally, the dynamics of religion can be viewed through two approaches: individualization and historical perspectives. The view of individualization is a uni-linear and coherent process, meanwhile, the history of religion perspective reveals diverse, temporary, and discontinuous processes. ${ }^{1}$

With regard to the view of individualisation about religiosity, the religiosity of individual is commonly inherrited from their parents that creates a passive act. Regarding this, parents who have a strong commitment to their religion take their children into pesantren so that their religiousness can enter the realm of thinking. However, individuals as adherents of religion are actually agents who are basically free to accept, reject, and change societal norms or community beliefs according to their individual beliefs, or vice versa. ${ }^{2}$

Little has been known about the view of individualisation about religiosity of Muslim professionals. This article takes Muslim professionals in Surabaya as a privileged case to examine how religious experiences are produced, represented, and discussed in regard to bidayah (guidance) in their daily life. Using a qualitative descriptive approach, this study has observed and interviewed Muslim professionals in Surabaya, East Java regarding bidayah as a social phenomenon in particular.

\section{The Social Reality of Hidayah Amongst Muslim Professionals}

Hidayah is commonly associated with someone who converts to Islam or connected to concept of repentance (tawbah), namely one feels regret and filled with remorse for his or her sins, turns to Allah intending to obey Him. It is a soft guidance for something to find ease on reaching a purpose. ${ }^{3}$

According to Ibnu Qayyim al-Jauziyah, bidāyab is divided into four forms: (a) general hidāyah-given to all creatures; (b) evidence, explanation, and understanding; (c) tawf $\bar{i} q$ or intended heart feeling on

\footnotetext{
1 Christoph Bochinger, Jörg Rüpke. "Dynamics of Religion: Past and Present," Proceedings of the XXI World Congress of the International Association for the History of Religions. Walter de Gruyter GmbH \& Co KG. 2016. pp. 1-8.

2 J. David Lewis and Richard L. Smith, American Sosiology and Pragmatism: Mead, Chicago Sociology, and Symbolic Interaction (Chicago: University of Chicago Press, 1980), p. 24.

3 Endang Syaifuddin Zuhri, Wawasan Islam (Yogyakarta: Pustaka Pelajar, 1986), p. 56.
} 
something valuable with a physical effort to get; (d) guidance from Allāh in the hereafter for them who obey Him. ${ }^{4}$

Meanwhile, Al-Marāghi also divided it into four forms of hidayah, they are (a) Al-Ilhäm referring to bidāyah as a form of gharizah (insting) that is given to all creature; (b) Al-Hawasy showing bidayah as a form of physical senses; (c) Al-A Aql meaning that hidayah is logic to think, understand and know something leading to truth and life safety; (d) $\mathrm{Al}$ Din taking hidayah as a divine guide that enables humans to distinguish between what is right and what is false, between good and bad, under the stipulation of Allāh. ${ }^{5}$

Whilst, Quraish Shihab divided bidayah into two kinds, the bidayahirsyad as guidance contented by religion values to other parts and/or to give example on how practising them; and hidayab-tawf $\overline{i q}$ which means religious guidance giving an individual the ability to do its contents. ${ }^{6}$

In addition, other experts, divided bidayah into two types, namely bidāab of religion (bidayat al-din) and bidayah of intellect (bidayah alaq). ${ }^{7}$ Both types of hidayah, 'aql and religion, work together to guide people to know who Allah is and how people translate Allah's attributes in their lives. In this sense, a person's understanding of Allāh is considered an intersubjective experience, namely how the human mind and heart interact in responding to existing realities, both natural and social. Hence, the social reality of bidayah is a social behavior where behavior changes from a disorder condition to an order behavior. This is an objective reality that can be observed through "why" and "how" question in regard to people's behaviour.

According to the theory of symbolic interactionism, the reality of bidayah can be observed by thinking that: (1) the truth or reality of pragmatism is actively created when someone takes action within and towards the world; (2) individual knowledge of the world is based on something that has been shown to benefit them; and (3) the actor is

4 Ibnu Qayyim al-Jauzīyah, Miftāh Dār Al-Sa ädah, vol. I (Beirut: Dār al-Kutub al'Ilmiyah, nd), p. 84-85.

5 Muḥammad Mushthafa al-Marāghi, Tafsìr Al-Maraghji, vol. I (Egypt: Maktabah Mushțafāa al-Bāb al-Ḥalabi, 1946), p. 34.

6 M. Quraish Shihab, Tafsir al-Misbah: Pesan, Kesan dan Keserasian al-Qur'an, Vol.II (Jakarta: Lentera Hati, 2005), p. 53.

7 Sitti Aisyah Chalik, Konsep Hidayah dalam al-Quran (Makassar: Alauddin University Press, 2012), p. 201. 
valued by the role he plays in the world. The ability to think as an actor needs to involve a number of stages, namely: determining objects in the social world, affirming modes of behavior, describing the consequences of a number of alternative actions, eliminating possibilities that are unlikely to occur, and choosing optimal actions.

\section{Hidayah and The Dinamics of Muslim Professionals' Religiosity}

The socio-religious dynamics in urban society have developed, expanded, and are fragmented. In the past, public religious meetings (pengajian umum) were held and attended by certain religious groups, where the majority came from the santri, Nahdlatul Ulama (NU) and Muhammadiyah. However, lately Islamic public preaching has been increasingly reaching out, especially since the 1980s, which is not only popular in the santri, but has penetrated the abangan community, even bureaucracy, and professional groups. Thus, nowadays there has been socio-religious mobility, especially among urban Muslim society. ${ }^{8}$

The advancement of communication technology also influences the religious dynamics of urban communities, including a shift in religious authority. In this regard, the way Muslim professionals study and understand religious teaching is more independent. An interviewed doctor said that he studied religion through campus discussions which lead to more radical thoughts. ${ }^{9}$ Another interviwed doctor has different religious experiences and perspectives, where religion is interpreted as a process of life's journey to surrender to Allāh. In this view, religion tends to be understood as a fatalism, which is completely surrendering God's destiny and power to him without effort. ${ }^{10}$

In addition, in the context of individual religious dynamics, worshippers try to externalize their religiosity as good as possible which is manifested through achievements in the workplace or in social activities. They also sacrifice their time and finances for the benefit of their group as evidence of their devotion to religion. ${ }^{11}$ The evidance can be seen from the result of interview towards an advocate who

\footnotetext{
8 Arif Afandi (ed.), Demokrasi Atas Bawab: Polemik Strategi Perjuangan Ummat Model Gus Dur dan Amin Rais (Yogyakarta: Pustaka Pelajar, 1996), p. 3.

9 Interview with an anonimous Muslim doctor, Surabaya, July 20, 2019.

10 Interview with an anonimous Muslim doctor working for a private hospital, Surabaya, July 20, 2019.

11 Scott Gordon, The History and Philosophy of Sosial Science (London and New York: Roudledge, 1991), p. 10.
} 
stated that religious practices is not only for reaching individual benefits, for materials in particular, but also for gaining social life purposes. The interviewed advocate acknoledged that the profession is not only to win at the court, but also to give a balance bargaining power fairly at law. Managing cases under legal considerations as well as with social and humanitarian considerations in a trustworthy, honest, fair, and in accordance with the professional code of ethics is part of our religious attitude. ${ }^{12}$

Similarly, other Muslim professionals said that having a positive attitude as pofessionals and doing job with relying on Allāh, will be able to contruct a positive and good environment in workplace as well. ${ }^{13}$ A profession that is carried out with mandate and full responsibility is able to bring about positive effects continuously, including with regard to material that has been arranged by Allāh. ${ }^{14}$ According to interviwees, actually, religion is influenced by the existing social structure surrounds, including family background. Religious leaders' children inherited their parents' religious attitudes too. In other words, parents' upbringing has a very strong influence on one's religious attitude. ${ }^{15}$ Life is a process towards religious attitudes and spirituality. ${ }^{16}$ In the context of a sociological perspective, the reality of bidayah is the professional ability of Muslims to internalize religious values, and then it is implemented when working in the workplace which is called social objectivation, in doing so they externalize with certain social realities around them, which is then produces a particular pattern of the religious reality of Muslim professionals ${ }^{17}$ In the context of Muslim professionals, a doctor who was born from santri family, priyayi and abangan will raise any mindset that religion is not being an obstacle for the profession, but it is likely to be a guideline and life guidance. ${ }^{18}$ For example, when a doctor was born from santri-

12 Advocate, "Interview Result," July 15, 2019.\& Notary, “Interview Result,” July 17, 2019.

13 Interview with an anonimous lecturer at state-owned university, Surabaya, July 25, 2019.

14 Interview with an anonimous lecturer at state-owned university, Surabaya, July 27, 2019.

15 Interview with an anonimous male Muslim preacher, Surabaya, August 2, 2019.

16 Interview with an anonimous male Muslim preacher, Surabaya, August 5, 2019.

17 Ibid.

18 Interview with an anonimous Muslim doctor, Surabaya, July 20, 2019. 
nabdliyin family, priyayi and abangan, he/she will think that patients could be more religious after taking treatment and get better. In this case, the human resources of hospital need to have any Islamic mindset to their services. ${ }^{19}$

In short, the dynamics of Muslim professionals' religiosity above illustrate that there is the interaction between religious bidayah and intellectual bidāah (bidāyat al-`aql).

\section{Hidayah and The Dynamics of Religiosity: A Social Theory Perspective}

Religious behavior consist of observable behavior and hidden behavior. ${ }^{20}$ Observable behavior is social action and interaction. Hidden behavior is a thought process that involves clear symbols and meanings of behavior. So what is meant by individual behavior here is behavior seen from the point of view of organized social group behavior. The human mind is seen as a social process which is defined as an internal communication with oneself through the use of meaningful symbols. With this internal communication, it allows individuals to take the role of other individuals in the interaction process.

The aspect of social-religiousity-situation could lead individuals to know and understand the meanings and the symbols used in Islam. For example, an individual is on Islamic situation, were he or she is a Muslim while it is cumpolsory for him/her to do the Maghrib prayer, automatically he or she follows to pray, but if he or she is not having a habit to practice it or even doing it congregationally at the mosque, they will know the lackness (e.g not having sufficient sürab or $d u^{\prime} \bar{a}$ recitations). It is only small part of affect when somebody practices salah. Here, it can be said that individual awareness (e.g is aforementioned) comes up in a certain situation, not purely coming from the thinking result.

Self-responding ability as people also respond to others, shape an ability to communicate to others. Here, what people saying, practice, are used to decide on what other people will do. The Mead Literacy was then developed and was spread wider by Blumer Symbolist

19 Interview with an anonimous Muslim doctor, Surabaya, July 20, 2019.

20 Bernard Meltzer, "Mead's Social Psychology," in J. Manis and B. Meltzer (ed.), Symbolic Interaction: A Reader in Social Psychology, 3rd Ed. (Boston: Allyn and Bacon, 1964), p. 23. 
Interactionist who used basic assumption that humankind has ability to think, it was shaoed from the social interaction. Thorugh thios interaction, people learned the emanings and symbols, things understood together then individual can produce action and reaction. ${ }^{21}$

There are no universality and objectivity on the meaning of the symbols, but individualistic and subjective. ${ }^{22}$ It is proven that an individual with Muslim situation could have more understanding on the meaning and muslim symbol while at the same time, it is a process of standardisation of pattern. This collective understanding of course vary depends on each individual transaction. It is a dynamic process where an actor shapes and adapts to needed informations as part of interaction. ${ }^{23}$ Therefore, there are repetitiveness and standard made inside the together action done time by time. ${ }^{24}$ The actors act in some situations shaped by massive scale structure or even bigger, directed by values which mostly have been accepted in its creation and re-creation, beside they actors also make any changes on those values.

Peter L. Berger ${ }^{25}$ has shared that there is only a bit of humans' behaviour which was decided by insting because they pushed to be dicispline on their experience as the basic consideration to decide. The long time dicipline, so that it can be said it was an intential (always run towards object) and the awareness to effect the external environment object. This point was so clear in his thesis which focus on explaining human and society as a process of dialectica of three moments: externalisation, objectivation and internalisation. Humankinds express themselves or do externalisation by building their own world and this shows that society, literally, is a social man made, an objective reality. It is separated from human and later face to face with human, it is called as objectivation. The next one is internalisation that human is shaped by society. ${ }^{26}$

21 George Ritzer, Contemporary Sociological Theory (New York: Alfred A. Knof, 1988), p. 181.

22 J. David Lewis and Richard L. Smith, American Sosiology and Pragmatism, p. 172.

23 Jerome Manis and Bernard Meltzer, Symbolic Interaction: A Reader in Social Psychology, Ed. 3 (Boston: Allyn \& Bacon, 1978), p. 6.

24 Herbert Blumer, "The Metodological Position of Symbolic Interactionism," in Herbert Blumer (ed.), Simbolic Interaction (Englewood Cliffs, N.J: Prentice-Hall, 1969), p. 17.

25 Peter L. Berger and Thomas Luckmann, The Social Construction of Reality (Garden City, N.Y: Anchor, 1967), p. 65.

26 Ibid. 
Islamic society as an objective reality in the pattern of collective understanding where individuals shape themselves through internalisation and surely it takes some steps of awareness based on their own complex internal transactions.

Beside that, actor also has motivation to act and level of this kind motivation is being a trigger of an individual action. Motivation provides a comprehensive plan to act, but mostly it is not a direct one because motivation is felt indirectly. According to Weber, ${ }^{27}$ the relationship between human and God is based on a point of view of function rather than atomistic where people act in their own world with their God. Here, Weber did not separate between social structures because they help each other to shape humankind full of value. To see this social action, Weber ${ }^{28}$ describes his focus on: 1) human action which according to the actor is valueable; 2) the real action which is subjective; 3) purposive actions done repeatedly because it has positive effects; 4) an action directed to an individual or many people; 5) an action due to other persons' direction.

Human repeats activities and continues them as actor. In a reflective situation, human (as an actor) will always be aware and monitor the activity cotinously. ${ }^{29}$ The actors make it possible to reach rationalisation or a process to develop routinely until they keep any knowlege about their actions. Motivation as a trigger to individual works too here. Giddens ${ }^{30}$ made differentiation between two awareness, the discursive (the ability to express something into words) and practical discursive (feels easy to express with no words). The practical one was used by Giddens further in his theory, Structurisation, an action which always ends differently from its thought and has an unintended consequence because of logical power (ability to make it different) as astart of subjectivity. The core of his theory $^{31}$ is the concept of structure, system and dualism of structure

27 Bryan S. Turner, Sebuah Studi Kritik tentang Weber dan Islam (Jakarta: Proyek Pembinaan PTA/IAIN, Direktorat Pembinaan Perguruan Tinggi Agama Islam, 1982), p. 80.

28 Max Weber, The Protestant Ethic and Spirit of Capitalism (New York: Scribner, 1958), p. 79.

29 Anthony Giddens, The Constitution of Society: Outline of The Theory of Structuration (Barkeley: University of California Press, 1984), p. 75.

30 Ibid.

31 Peter L. Berger and Thomas Luckmann, The Social Construction of Reality, p. 111. 
itself. Structure is a regulation and source, making any relation between space and time in social system. This character makes a social system to exist and to pass the space and time in shaping systemic siatuation.

Moreover, social system is a reproduced social behaviour conducted by actors or organised groups as a regualr thing. It has no structure, but shows a character of structure. Then, it is applied into social systems (especially when the practice of reproduction of space and time-macro), also into remembering (micro memory) which has orientation to understandable human agents behaviour. It can be said that structure is not coming from outside parts, but inside the remembering (memory) and social practice (social system).

Its social life is not out of their souls, but unite into individual choice as an alternative to do something because structure is not outside the actor. Berger and Luckman suggest that the objective institutional world basically needs legitimation or a way to explain its truth. ${ }^{32}$ There, legitimation function is cognitive, to give guide on how somebody should behave to keep his or her religiousity reality.

Religion is a symbol of universe to give meaning on human life and give exlaination comprehensively about reality. It is also a sacral canopy which protects human from chaos (a situation with no meaning). Not only them, religion legitimates social institution into its sacred and cosmic framework, where by this it teachs that religion takes also a role as the most effective legitimation form. ${ }^{33}$

For Geertz, religion is a system of accepted symbol to decide hearts and strong motivation, deep feeling on qalb (heart-soul), and put it longlasting inside human. ${ }^{34}$ It is a belief system owned by individuals and practiced by some parts or the whole society. ${ }^{35}$ Islam is an aqidah system that manages anything in life and humanity in various aspects, whether the relation between human to God and human to sesame or even human to nature (organics, animals, etc). ${ }^{36}$ To add more, Hasbi Ash Shiddiqie ${ }^{37}$ manintains that anybody who is a

32 Margaret Poloma, Sosiologi Kontemporer (Jakarta: Rajawal Pers, 1992), p. 310.

33 Peter L. Berger and Thomas Luckmann, The Social Construction of Reality, p. xvi.

34 Clifford Geertz, Kebudayaan dan Agama (Yogyakarta: Kanisius, 1992), p. 310.

35 Robertson Ronald, Agama: Dalam Analisa dan Interpretasi Sosiologi Jakarta: Rajawali Pers, 1988), p. vi.

36 Endang Syaifuddin Zuhri, Wawasan Islam, p. 19.

37 Ibid. 
Muslim could defined as (1) believing in (heart believes, mouth speaks, and practice the deeds) Allah (God), Malä'ikah (Islamic angels), Kitäb (the holybook), qiyamah (hereafter) and taqdir (destiny); (2) practicing the the pillars of Islam: stating the shabadah, doing the salah, observing the fasting in Ramadhan, spending the zakāh and performing the hajj; (3) practicing ihssan (sincereness, khushü, follow the spirit of Iman and Islam).

With the wealth, Muslims have an ease and freedom to fulfill their religious emotion individually and socially. That is because Islam is not not an individual religion (only between a human and Allāh), but also a social religion (other person or society around can observe Muslims' way of life).

\section{Conclusion}

Initially, the religious bidayah that comes into the human heart is merely a recording of a social process. However, at the next stage of life's journey, the environment offers a challenge for religion as well as personal thinking and action. The religious capital that is bestowed on a person from childhood continues to develop according to the choices available in a wider social life. Every single person then finally has a certain and more assertive pattern of action.

It is in this context that every choice of action taken by Muslim professionals is actually in line with their various past experiences, although not against the realm of their profession. The guidance of religion and the admonition of reason are intertwined in determining the social actions of Muslim professionals, giving rise to the complementary religious dynamics among themselves. []

\section{References}

Afandi (ed), Arif. Demokrasi Atas Bawah: Polemik Strategi Perjuangan Ummat Model Gus Dur dan Amin Rais. Yogyakarta: Pustaka Pelajar, 1996.

Berger, Peter L., and Thomas Luckmann. The Social Construction of Reality. Garden City, N.Y: Anchor, 1967. 
Blumer, Herbert. "The Metodological Position of Symbolic Interactionism." in Herbert Blumer (ed.), Simbolic Interaction. Englewood Cliffs, N.J: Prentice-Hall, 1969.

Chalik, Sitti Aisyah. Konsep Hidayah dalam al-Quran. Makassar: Alauddin University Press, 2012.

Geertz, Clifford. Kebudayaan dan Agama. Yogyakarta: Kanisius, 1992.

Giddens, Anthony. The Constitution of Society: Outline of the Theory of Structuration. Barkeley: University of California Press, 1984.

Gordon, Scott. The History and Philosophy of Sosial Science. London and New York: Roudledge, 1991.

al-Jauzìnah, Ibnu Qayyim. Miftặ Dār Al-Sa adah, vol. I. Beirut: Dār alKutub al-'Ilmīyah, nd.

Lewis, J. David, and Richard L. Smith. American Sosiology and Pragmatism: Mead, Chicago Sociology, and Symbolic Interaction. Chicago: University of Chicago Press, 1980.

Maddox, Marion. For God and Country: Religious Dynamics in Australian Federal Politics. Department of the Parliamentary Library Canberra, 2001.

Manis, Jerome, and Bernard Meltzer. Symbolic Interaction: A Reader in Social Psychology, Ed. 3. Boston: Allyn \& Bacon, 1978.

al-Marāghi, Muhammad Mushțafa. Tafsìr al-Marāghī, vol. I. Mesir: Maktabah Mușțafa al-Bāb al-Ḥalabi, 1946.

Meltzer, Bernard. "Mead's Social Psychology." in. J. Manis and B. Meltzer (Ed.). Symbolic Interaction: A Reader in Social Psychology, 3rd Ed. Boston: Allyn and Bacon, 1964.

Poloma, Margaret. Sosiologi Kontemporer. Jakarta: Rajawali Pers, 1992.

Ritzer, George. Contemporary Sociological Theory. New York: Alfred A. Knof, 1988.

Ronald, Robertson. Agama: Dalam Analisa dan Interpretasi Sosiologi. Jakarta: Rajawali Pers, 1988.

Shihab, M. Quraish. Tafsir al Misbah: Pesan, Kesan dan Keserasian al-Qur'an, Vol. II. Jakarta: Lentera Hati, 2005. 
Turner, Bryan S. Sebuah Studi Kritik tentang Weber dan Islam. Jakarta: Proyek Pembinaan PTA/IAIN, Direktorat Pembinaan Perguruan Tinggi Agama Islam, 1982.

Weber, Max. The Protestant Ethic and Spirit of Capitalism. New York: Scribner, 1958.

Zuhri, Endang Syaifuddin. Wawasan Islam. Yogyakarta: Pustaka Pelajar, 1986.

\section{List of Interviews:}

Interview with an anonimous Muslim doctor, Surabaya, July 20, 2019.

Interview with an anonimous Muslim doctor working for a private hospital, Surabaya, July 20, 2019.

Interview with an anonimous lecturer at state-owned university, Surabaya, July 25, 2019.

Interview with an anonimous lecturer at state-owned university, Surabaya, July 27, 2019.

Interview with an anonimous male Muslim preacher, Surabaya, August 2, 2019.

Interview with an anonimous male Muslim preacher, Surabaya, August 5, 2019. 